\title{
Expression of the Gene Encoding Secretor Type Galactoside $2 \alpha$ Fucosyltransferase (FUT2) and CD44 Marker in Urogenital Tumors
}

\author{
M. A. Ensinck, N. Lebensohn, S. García Borrás, L. Racca, C. Cotorruelo, C. Biondi \\ Area Immunology, Department of Clinical Biochemistry, National University of Rosario, Rosario, Argentina \\ Email: cbiondi@fbioyf.unr.edu.ar
}

How to cite this paper: Ensinck, M.A., Lebensohn, N., Borrás, S.G., Racca, L., Cotorruelo, C. and Biondi, C. (2016) Expression of the Gene Encoding Secretor Type Galactoside $2 \alpha$ Fucosyltransferase (FUT2) and CD44 Marker in Urogenital Tumors. Open Journal of Genetics, 6, 96-104.

http://dx.doi.org/10.4236/ojgen.2016.64011

Received: November 11, 2016

Accepted: December 20, 2016

Published: December 23, 2016

Copyright $\odot 2016$ by authors and Scientific Research Publishing Inc. This work is licensed under the Creative Commons Attribution International License (CC BY 4.0).

http://creativecommons.org/licenses/by/4.0/

\begin{abstract}
The aim of this work was to investigate the FUT2 gene, the secretor status and the expression of CD44 protein in epithelial cells obtain from saliva and urine samples from patients with urogenital tumours. We studied 104 subjects. Half of them had urogenital tumours, while the other half was the healthy control group. We determined the secretor status in saliva with the haemagglutination inhibition technique. We analyzed the FUT2 polymorphism by allele specific oligonucleotide-polymerase chain reaction (ASO-PCR) with specific primers for the G428 allele and the wild type allele of FUT2 gene. We found higher intensity of urogenital disease in the non-secretor group $(\mathrm{OR}=3.44)$. In contrast with the healthy population, $51.6 \%$ of the patients with potential malignant urogenital lesions and cancerous lesions were nonsecretors. We also investigate by confocal microscopy, the expression of CD44 protein in epithelial cells obtained from urine samples from these patients. The results obtained also showed fluorescence corresponding to the presence of CD44 protein in samples from patients diagnosed with cancer. Our study suggests that the lack of wild type FUT2 gene and a nonsecretor status appear to be an associated risk marker for the development of urogenital tumors. Several mechanisms, based on the properties of CD44 as the major hyaluronan CD44 in cell carcinomas receptor, have been proposed to explain the role of elevated CD44 expression during tumour development and progression. CD44 might be a good candidate as a predictor of prognosis in this group of cancers.
\end{abstract}

\section{Keywords}

FUT2, Secretor Status, Tumours, Urogenital

\section{Introduction}

In cancer biology, cancer cell progression is defined by increased proliferation, inva- 
sion, migration, and metastasis of cancerous cells to other parts of the body. Tumor cell heterogeneity plays a major role in cancer progression and metastasis [1]. Surgical, radio, chemotherapeutic and biological treatments have experienced important advances, with concomitant reduction in the morbidity associated with the radical surgical practices of the past [2].

The diagnosis of urogenital lesions especially the prostatic adenocarcinoma is challenging and surprising to the pathologist. As these carcinomas have various histomorphological patterns of presentation with minimal cytological and architectural atypia in limited tissue fragment like needle biopsy [3] [4].

Bladder tumors include a variety of benign and malignant entities and, although not uncommon in adults, they are rare in children.

The prostate gland is of paramount importance for human disease due to the increasing incidence of benign prostatic hyperplasia and prostate carcinoma in aging men. Prostate carcinoma now represents the second leading cause of cancer death in American men Nonetheless, little is known about the molecular factors that contribute to the onset or progression of prostate cancer. A primary impediment for identifying relevant molecular factors has been the paucity of information regarding the mechanisms of normal prostate growth and differentiation. The histomorphological variants in prostatic tumor like atrophic, foamy gland, pseudohyperplastic and certain subtypes of ductal adenocarcinoma represent the most common causes of under-diagnosed cancer [5].

Tumor progression is often associated with altered glycosylation of the cell-surface proteins and lipids. The peripheral part of these cell-surface glycoconjugates often carries carbohydrate structures related to the $\mathrm{ABO}$ and Lewis blood group antigens. The expression of histo-blood group antigens in normal human tissues is dependent on the type of differentiation of the epithelium.

The $\mathrm{ABO}$ blood group antigens are among the well-known fucosylated glycans. The expression of them is regulated by several glycosyltransferases that add monosaccharides to a precursor molecule in a sequential fashion [6] [7]. The expression and secretion of $\mathrm{ABO}$ antigens in epithelial cells are controlled by secretor type $\alpha(1,2)$ fucosyltrans-ferase activity, known as the Secretor (Se) transferase (FUT2 gene product). Several different polymorphisms are known in the FUT2 gene, some called as silent mutations, while others as to non-functional enzymes [7] [8].

The $\mathrm{H}$ antigen, which is a precursor of $\mathrm{A}$ and $\mathrm{B}$ antigens, is synthesized by $\alpha(1,2)$ fucosyltransferase. It has been demonstrated that two distinct $\alpha(1,2)$ fucosyltransferases are present in human tissues [6]. One is the $H$ gene (FUT1)-encoded $\alpha(1,2)$ fucosyltransferase ( $\mathrm{H}$ enzyme) that regulates expression of $\mathrm{ABH}$ antigens in erythrocytes, and the other is the Secretor gene (FUT2)-encoded $\alpha(1,2)$ fucosyltransferase (Se enzyme) that regulates expression of $\mathrm{ABH}$ antigens in the gastrointestinal tract and secretions. Secretors, who have $\mathrm{ABH}$ antigens in saliva, have at least one functional Se allele, and non secretors, who fail to express $\mathrm{ABH}$ antigens in their saliva, are homozygous for the nonfunctional se allele [9] [10].

The functional significance for $\mathrm{ABO}$ antigen expression on erythrocytes has not been defined, but ABO-related structures may play a role in other systems. Alterations in the 
expression of fucosylated oligosaccharides have also been observed in several pathological processes, including cancer and atherosclerosis [11] [12] [13].

It is well established that the large array of functions that a tumour cell has to fulfill to settle as a metastasis in a distant organ requires cooperative activities between the tumour and the surrounding tissue and that several classes of molecules are involved, such as cell-cell and cell-matrix adhesion molecules and matrix degrading enzymes, to name only a few. Cell adhesion molecules are found on the surfaces of all cells, where they bind to extracellular matrix molecules or to receptors on other cells. Cell adhesion is critical in the dynamic processes necessary for tissue morphogenesis in development and the maintenance of complex differentiated tissues in adult organisms. Adhesion molecules have originally been thought to be essential for the formation of multicellular organisms and to tether cells to the extracellular matrix or to neighbouring cells. [14]. CD44 is the major human cell surface receptor for hyaluronate and functions in a diverse range of physiological processes. CD44 may play a role in stimulating in vivo aggressiveness of tumors through hyaluronate-rich stroma [15]. Several experimentally verified CD44v forms have been shown to be directly involved in many malignant tumors and some correlate with metastatic progression [16]. Numerous studies based on immunohistochemical analyses of paraffin-embedded or frozen tissue sections using different monoclonal antibodies to CD44 isoforms and molecular biological techniques have provided evidence that in many types of tumours there is over expression of CD44 isoforms [17].

In the present study we investigate the FUT2 gene, the secretor status and the expression of CD44 protein in epithelial cells obtain from saliva samples or urine in patients with urogenital tumors.

\section{Materials and Methods}

The patients analyzed in this study presented to the Urology Department of the Medicine Faculty of the National University of Rosario, in a range of age between 44 and 92 years. Recruitment was made by consecutive sampling for a period of 24 months.

From a total of 104 subjects examined, half suffered from urogenital tumors (bladder, prostatic and kidney) and benign lesions (benign prostatic hyperplasia) while the other half was the healthy control group. Patients with testicular tumors were excluded from this study. All were subjected to clinical examinations and standard evaluation tests in order to establish the secretor status of their saliva. In the group of patients with cancerous lesions (experimental group), a histopathological examination was performed. No patient received prior hormonal therapy.

All subjects gave informed consent to participate in the study, and the protocol was approved by the Ethic Committee of the School of Biochemestry Sciences of Rosario, Argentina, according to the principles of the Declaration of Helsinki.

\subsection{Inhibition Test for Secretor Status [18]}

2 or $3 \mathrm{~mL}$ of saliva were collected into wide mouthed tubes. In order to eliminate the 
mucine protein they were treated with thermal shocks. They were centrifuged and the supernatant were transferred to a clean test tube and placed in boiling water bath for 10 minutes to inactivate salivary enzymes. To 1 drop of appropriately diluted blood grouping reagent (anti-A, anti-B or ulex europeaus) we added 1 drop of patient's saliva. We incubated 10 minutes at room temperature and then we added 2 drops of $2 \%$ to $5 \%$ saline suspension of washed indicator red cells. Then, the tube was incubated 30 minutes and centrifuged in order to inspect cell button macroscopically for agglutination.

Agglutination of indicator cells by antibody in tubes containing saliva indicates that the saliva does not contain the corresponding antigen (non secretor status, se). Failure of known antibody to agglutinate indicator cells after incubation with saliva indicates that the saliva contains the corresponding antigen (secretor status, Se).

\subsection{Molecular Studies [19]}

\section{- DNA isolation}

Genomic DNA was isolated from saliva samples. We designed a protocol for DNA extraction from these samples. They were subjected to thermal shock by successive freezing and thawing and centrifuged to work with the cell button. We used the technique CTAB/DTAB (dodecyltrimethylammoniumbromide/cetyltrimethylammoniumbromide) adding CTAB directly without the addition of TE buffer] The DNA concentration was measured spectrophotometrically at $260 \mathrm{~nm}$ and diluted in sterile water to a concentration of $100 \mathrm{ng}$ per $\mu \mathrm{L}$.

- G428A polymorphism

The DNA samples were analyzed by ASO-PCR (allele specific oligonucleotid-polymerase chain reaction) with specific primers (Operon Lab) for G428A allele and the wild type allele of FUT2 gene (Table 1). A fragment of $132 \mathrm{bp}$ was amplified as described by Henry et al. except for modifications of the annealing temperature according to the Tm of the primers.

\subsection{CD44}

We investigated by confocal microscopy, the expression of CD44 protein in epithelial cells obtained from urine samples from patients with urogenital tumours. We studied 48 patients with various tumours, and a control group $(\mathrm{n}=32)$ who had no alterations. We worked with urine samples washed with phosphate buffered saline. They were concentrated by centrifugation. Then, the cells were incubated with anti-CD44 antibody suitable dilution for $30 \mathrm{~min}$ at room temperature. After washing with phosphate buffered saline, it was incubated with secondary antibody labeled with allophycocyanin

Table 1. Sequence of primers for the analysis of the G428A mutation.

\begin{tabular}{cccc}
\hline Primer & Tm & Sequence & Specificity \\
\hline FUT2-Se-428-s & $68.8^{\circ} \mathrm{C}$ & 5'-CCGGTACCCCTGCTCGTG-3' & Se (direct) \\
FUT2-se-428-f & $66.6^{\circ} \mathrm{C}$ & $5^{\prime}$-ACCGGTACCCCTGCTCGTA-3' & se (direct) \\
FUT2-all-523-as & $66.7^{\circ} \mathrm{C}$ & 5'-CCGGCTCCCGTTCACCTG-3' & No specífic (reverse) \\
\hline
\end{tabular}


(APC). Parallel internal controls were processed for each sample. The different cell suspensions were washed with phosphate buffered saline and observed by confocal microscopy (Nikon C1) using $639 \mathrm{~nm}$ red laser.

\subsection{Statistical Analysis}

The categorical data were examined with a $\mathrm{x}^{2}$ test, and the ORs were estimated using an unconditional logistic model.

\section{Results}

In our population the nonsense mutation ( $428 \mathrm{G}-\mathrm{A}$ ) in the FUT2 gene is the most frequent polymorphism. We studied the possible association between the $428 \mathrm{G}-\mathrm{A}$ in the FUT2 gene and urogenital tumours 。

The $77.5 \%$ of the healthy individuals studied posses the Se gene that governs the secretion of water-soluble ABH antigens into saliva (secretor status). These secreted antigens can be demonstrated in saliva by agglutination inhibition tests with $\mathrm{ABH}$ antisera. The $51.6 \%(\mathrm{n}=16)$ of the patients with urogenital cancerous was non secretors (se), $(\mathrm{RO}=2.44$; IC $95 \%(0.7836 ; 7.5534)(\mathrm{p}=0.12)$ in contrast with the healthy population (Table 2). The molecular analysis also showed that $51.6 \%$ of patients was homozygous for the G428A mutation (the mutation present in the 2 alleles), the other patients were homozygous for the secretor status (none of them presented the allele G428A), or heterozygous secretor ( 1 allele presented with the mutation G428A) Figure 1. The 28.6\% $(n=6)$ of the patients with benign prostatic hyperplasia was non secretors. We observed a marginal association between secretor status (Se) and these lesions.

The results obtained with confocal microscopy showed fluorescence corresponding to the presence of CD44 protein in samples from patients diagnosed with cancer. A higher intensity was observed in individuals with a pathological diagnosis of urogenital cancer. In contrast, samples from patients with benign lesions showed no fluorescence images as samples of the control group (Figure 2).

\section{Discussion}

It is important to diagnose cancer in its early stages, since the management of small and localized tumors involves less morbidity and mortality than more advanced-stage disease, where treatment must be more aggressive. Indeed, the stage in which the disease is diagnosed is directly correlated to long-term survival [20]. Biochemical and molecular genetic studies have contributed to our molecular knowledge of blood group-associated molecules in the past few years.

Table 2. Secretor status in patients with urogenital lesions.

\begin{tabular}{ccc}
\hline & $\begin{array}{c}\text { Benign lesions } \\
\text { (benign prostatic hyperplasia) }\end{array}$ & $\begin{array}{c}\text { Urogenital tumours } \\
\text { (bladder, prostatic and kidney) }\end{array}$ \\
\hline FUT2-Se (Secretor Status) & 15 & 15 \\
FUT2-se (No Secretor Status) & 6 & 16 \\
\hline
\end{tabular}




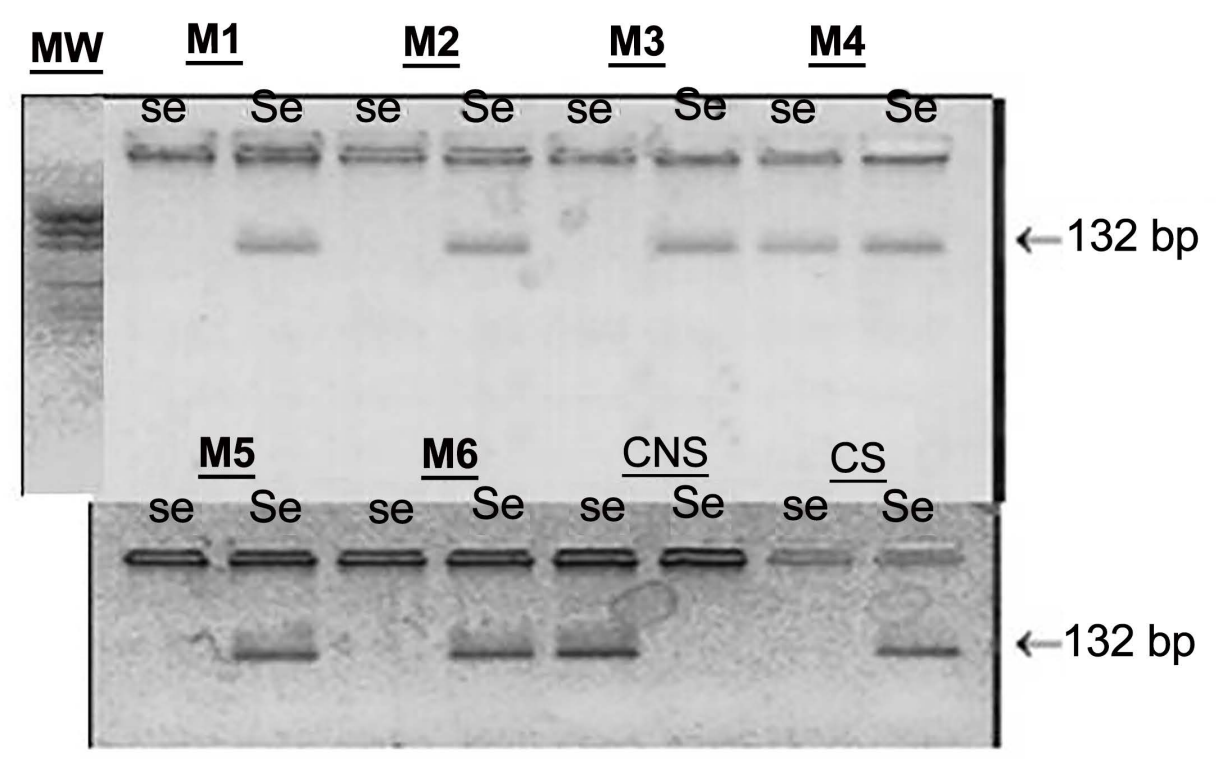

Figure 1. The agarose gel show the PCR products of $132 \mathrm{bp}$ for the M1-M6 Samples. Each sample was analysed for the wild type allele (Se) and for G428A allele (se) and was run together with ssecretor control (CS), non-secretor control (CNS) and molecular weight marker (MW).

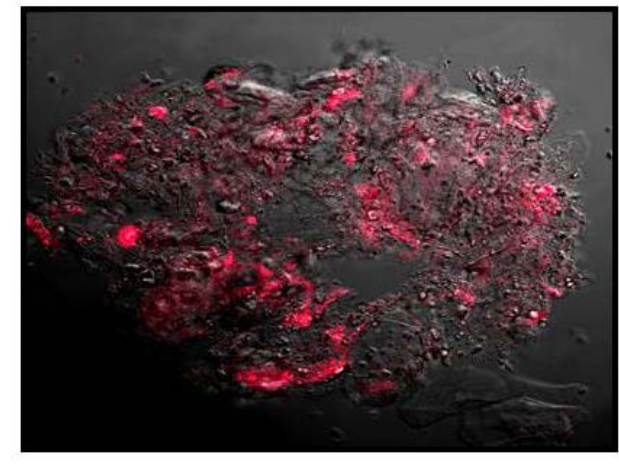

(a)

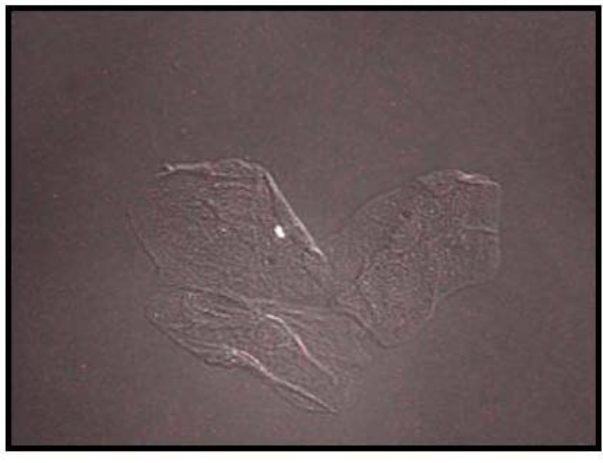

(b)

Figure 2. (a) Image of carcinoma cells obtained by confocal microscory The over expression of CD44 protein is noted by the red fluorescence observed on cell membranes and in cytoplasms; (b) Image of benign lesions calls obtained by confocal microscory No red fluorescence is observed the adsence of CD44 protein expression.

Blood-group antigens can be present on key receptors controlling cell proliferation, adhesion, and motility, such as epidermal growth factor receptor, integrins, cadherins, and CD44.

It is well-established that human gene frequencies for the ABO blood groups vary in a society, thereby leading to a risk factor for many diseases. Recently, there has been a trend of linking blood groups and several diseases [21].

Although the $\mathrm{ABO}$ blood group antigens were initially identified, by Landsteiner, as erythrocyte substances with a significance mainly ascribed to serology, it soon became clear that these antigens were found on most epithelial cells and in secretions. Today 
the molecular and genetic basis of the $\mathrm{ABH}$ and Lewis systems and the associated secretory phenotypes has been resolved [22]. The secretor gene (FUT2) codes for an $\alpha(1$, 2) fucosyltransferase that determines the $\mathrm{ABH}$ secretor status.

The results obtained in this work, have demonstrated that the large majority of the people examined in the healthy group were Se and there were significant difference between secretors and non-secretors in the experimental group. We also found a higher intensity of urogenital disease in this group, and the occurrence of epithelial dysplasia was most found in this group. The studies of patients with malignant lesions, in which non-secretor status predominates, appear to be an associated risk marker for the development for urogenital cancer.

This study evaluated the association between urogenital lesions and polymorphisms of the Se genes. We found that cancerous lesions were increased among individuals with non secretor status and nonsense mutation $428 \mathrm{G} \rightarrow \mathrm{A}$ (Trp143 $\rightarrow$ stop) (51.6\%). We found 16 patients diagnosed histopathologically as malignant lesions despite the secretory status.

$\mathrm{CD} 44$ is a transmembrane glycoprotein that binds hyaluronan, extracellular matrix proteins and growth factors. Alternative splicing of a single gene generates a family of splice variants (CD44vl-10) in addition to the standard isoform. Cell adhesion molecules are essential for maintaining the stable structure of stratified squamous epithelium. In normal epithelium, keratinocytes are attached to each other and to the underlying basement membrane. Cell adhesion, however, must be dynamic to facilitate the mobility and turnover of cells. In dynamic situations, keratinocytes alter their cell-cell and cell-ECM interactions by virtue of altered expression and function of cell adhesion molecules. The expression of cell adhesion molecules is normally tightly regulatedforming, persisting, or declining in an ordered fashion. This allows for controlled cell proliferation, mobility, differentiation, and survival. Many of these processes are misregulated in malignant tumours, and it has been shown that many of the characteristics of tumour cells are attributable to the aberrant expression or function of cell adhesion molecules. However, multiple CD44 isoforms are expressed by normal stratified squamous epithelia, such as the epidermis and the lining of the oral cavity [15].

The neoplastic transformation of normal epithelial cells to metastatic tumour cells is a complex process involving a number of alterations in the expression of genes implicated in cell proliferation, cell adhesion and cell migration. Tumour progression is the process by which tumour cells acquire malignant properties, such as progressive growth, invasion and metastasis. One of the genes involved in these processes is CD44 which appears to be one of the most promising candidates as a cancer diagnosis marker [23].

We investigate by confocal microscopy, the expression of CD44 protein in epithelial cells obtained from urine samples from patients with urogenital lesions. The results obtained showed fluorescence corresponding to the presence of CD44 protein in samples from patients diagnosed with cancer. A higher intensity was observed in individuals with a pathological diagnosis of carcinoma (Figure 2). In contrast, samples from patients with benign lesions showed no fluorescence images as samples of the control 
group (Figure 2). These findings indicate that overexpression of CD44 molecule analyzed could be considered as a marker of risk in individuals with oral lesions. CD44 might be a good candidate as a predictor of prognosis in this group of cancers.

\section{Conclusion}

In summary, our results indicate that at the same time as the morphological changes that occur during the process of carcinogenesis, another series of events occurs [24]. Further follow-up studies are required to clarify the role of predictive markers of risk in precursor lesions of urogenital cancer.

\section{References}

[1] Bryne, M., Boysen, M., Alfsen, C.G., et al. (1998) The Invasive Front of Carcinomas. The Most Important Area for Tumour Prognosis? Anticancer Research, 18, 4757-4764.

[2] Greenlee, R., Hill-Harmon, M., Murray, T. and Thun, M. (2001) Cancer Statistics. $C A: A$ Cancer Journal for Clinicians, 51, 15-36. https://doi.org/10.3322/canjclin.51.1.15

[3] Shah, R. and Zhou, M. (2009) Interpretation of Prostate Needle Biopsies. Benign Mimics of Prostate Cancer and Unusal Cancer Morphologies Which Mimic Benign Conditions. USCAP Annual Meeting. http://www.uscap.org/site /98th/shorth13-5.htm

[4] Arista-Nasr, J., Martínez-Benítez, B., Fernández-Amador, J.A., Bornstein-Quevedo, L. and Albores-Saavedra, J. (2010) Pseudohyperplastic Carcinoma with Xanthomatous Changes: A Neoplasm Mimicking Glandular Hyperplasia of the Prostate. Actas Urológicas Españolas, 34, 333-339. https://doi.org/10.1016/j.acuro.2009.09.011

[5] Mazerolles, C. and Chevreau, C. (2007) Tumeur Malignes Rares de la Prostate. Bulletin du Cancer, 94, F44-F49.

[6] Cartron, J. and Rouger, P. (2001) Bases molèculaires des antigènes des groupes sanguins. De l'immunogenètique à la bioilogic cellulaire, 3rd Edition.

[7] Yamamoto, F. (2004) Review: ABO Blood Group System. ABH Oligosaccharide Antigens, Anti-A y Anti-B, A and B Glycosyl Transferases, and ABO Genes. Immunohematology, 20, 3-17.

[8] Henry, L., Oriol, R. and Samuelsson, B. (1995) Lewis Histo-Blood Group System and Associated Secretory Phenotypes. Vox Sanguinis, 69, 166-182. https://doi.org/10.1111/j.1423-0410.1995.tb02591.x

[9] Nishihara, S., Hiraga, T., Ikehara, Y., Kudo, T., Iwasaki, H., Morozumi, K., et al. (1996) Molecular Mechanisms of the Alternative Names of Secretor (Se) and Lewis (Le) Enzyme Are FUT2 or Fuc-T II, and FUT3 or Fuc-T III, Respectively. 976 Polymorphisms of TwoFucosyltransferase Genes Expression of Lewis b Antigen Andother Type I Lewis Antigens in Human Colorectal Cancer. Glycobiology, 9, 607-617.

[10] Nishihara, S., Narimatsu, H., Iwasaki, H., Yazawa, S., Akamatsu, S., Ando, T., et al. (1994) Molecular Genetic Analysis of the Human Lewis Histo-Blood Group System. The Journal of Biological Chemistry, 269, 29271-29278.

[11] Henry, S., Orio, R. and Samuelsson, B. (1995) Lewis Histo-Blood Groupsystem and Associated Secretory Phenotypes. Vox Sanguinis, 69, 166-182.

https://doi.org/10.1111/j.1423-0410.1995.tb02591.x

[12] Hakomori, S. (1999) Antigen Structure and Genetic Basis of Histo-Blood Groups A, B and O: Their Changes Associated with Human Cancer. Biochimica et Biophysica Acta, 1473, 
247-266. https://doi.org/10.1016/S0304-4165(99)00183-X

[13] Campi, C., Escovich, L., Moreno, A., Racca, L., Racca, A., Cotorruelo, C., et al. (2012) Expression of the Gene Encoding Secretor Type Galactoside $2 \alpha$ Fucosyltransferase (FUT2) and $\mathrm{ABH}$ Antigens in Patients with Oral Lesions. Medicina Oral Patologia Oral y Cirugia Bucal, 17, e63-e68. https://doi.org/10.4317/medoral.17239

[14] Marhaba, R. and Zöller, M. (2004) CD44 in Cancer Progression: Adhesion, Migration and Growth Regulation. Journal of Molecular Histology, 35, 211-231. https://doi.org/10.1023/B:HIJO.0000032354.94213.69

[15] Hudson, D., Speight, P. and Watt, F. (1996) Altered Expression of CD44 Isoforms in Squamous-Cell Carcinomas and Cell Lines Derived from Them. International Journal of Cancer, 66, 457-463. https://doi.org/10.1002/(SICI)1097-0215(19960516)66:4<457::AID-IJC8>3.0.CO;2-V

[16] Assimakopoulos, D., Kolettas, E., Patrikakos, G. and Evangelou, A. (2002) Therole of CD44 in the Development and Prognosis of Head Andneck Squamous Cell Carcinomas. Histology and Histopathology, 17, 1269-1281.

[17] Liu, J. and Jiang, G. (2006) CD44 and Hematologic Malignancies. Cellular \& Molecular Immunology, 3, 359-365.

[18] Brecher, M., Butch, S., Calhoun, A., Fiebig, E., et al. (2012) Manual Técnico Asociación Americana de bancos de sangre. 17th Edition.

[19] Sambrook, J., Fritsch, E.F. and Maniatis, T. (1982) Molecular Cloning: A Laboratory Manual. 2nd Edition, Cold Spring Harbor Laboratory Press, New York.

[20] Jemal, A., Bray, F., Center, M.M., Ferla, J. and Ward, E. (2011) Global Cancer Statistics. $C A$ : A Cancer Journal for Clinicians, 61, 69-90. https://doi.org/10.3322/caac.20107

[21] Dentali, F., Sironi, A.P., Ageno, W., Turato, S., Bonfanti, C., Frattini, F., Crestani, S. and Franchini, M. (2012) Non-O Blood Type Is the Commonest Genetic Risk Factor for VTE: Results from a Meta-Analysis of the Literature. Seminars in Thrombosis and Hemostasis, 38, 535-548. https://doi.org/10.1055/s-0032-1315758

[22] Kelly, R., Rouquier, S., Giorgi, D., Lennon, G. and Lowe, I. (1995) Sequence and Expression of a Candidate for the Human Secretor Blood Group $\alpha(1,2)$ Fucosyltransferase Gene (FUT2). Homozygosity for an Enzyme-Inactivating Nonsense Mutation Commonly Correlates with the Non-Secretor Phenotype. Journal of Biological Chemistry, 270, 4640-4649. https://doi.org/10.1074/jbc.270.9.4640

[23] Otavia, L., Caballero, L., de Souza, S., Bretani, R., Simpson, A. (2001) Alternative Spliced Transcripts as Cancer Markers. Disease Markers, 17, 67-75. https://doi.org/10.1155/2001/184856

[24] Secretor Status (2016) Fut2 Gene and ABH Antigens in Urogenital Tumors Ensinck MA1, Lebensohn N2, García Borrás S3, Racca L4, Cotorruelo C5, Biondi C. IJOER: Engineering Journal, 2, 43-48. 
Submit or recommend next manuscript to SCIRP and we will provide best service for you:

Accepting pre-submission inquiries through Email, Facebook, LinkedIn, Twitter, etc. A wide selection of journals (inclusive of 9 subjects, more than 200 journals)

Providing 24-hour high-quality service

User-friendly online submission system

Fair and swift peer-review system

Efficient typesetting and proofreading procedure

Display of the result of downloads and visits, as well as the number of cited articles

Maximum dissemination of your research work

Submit your manuscript at: http://papersubmission.scirp.org/

Or contact ojgen@scirp.org 